www.scientiaplena.org.br

\title{
Swat model for in potential contamination a tributary of the rio São Francisco, Brazil
}

\author{
Aplicação do modelo SWAT para avaliar o potencial de contaminação por agrotóxicos num \\ afluente do rio São Francisco, Brasil \\ F. B. Britto ${ }^{1 *}$; A. O. Aguiar Netto $;$ A. N. do Vasco $;$ M. G. Silva ${ }^{3}$ \\ ${ }^{1}$ Instituto Federal de Sergipe - Campus Aracaju/IFS, 49100-000: São Cristovão - SE, Brasil \\ ${ }^{2}$ Departamento de Agronomia, Universidade Federal de Sergipe/ UFS, 49100-000: São Cristovão - SE, Brasil \\ ${ }^{3}$ Instituto Federal de Sergipe - Campus São Cristóvão/IFS, 49100-000: São Cristovão - SE, Brasil
}

*anderovasco@yahoo.com.br

(Recebido em 13 de junho de 2017; aceito em 28 de setembro de 2017)

\begin{abstract}
O uso e ocupação do solo nas planícies inundáveis na bacia hidrográfica do rio Betume vem acarretando graves impactos ambientais entre eles: contaminação do solo e água por agrotóxicos provenientes da agricultura e pecuária. A modelagem ambiental é uma ferramenta útil para subsidiar a gestão e o manejo de uma bacia hidrográfica, permitindo prever os diferentes impactos das atividades antrópicas na água e no solo. O modelo SWAT (Soil and Water Assessment Tool) permite avaliar impactos provocados pela alteração do uso do solo sobre os processos hidrológicos e a dinâmica de agrotóxicos em uma bacia hidrográfica. Este estudo tem como objetivo simular a potencialidade de contaminação dos agrotóxicos no rio Betume, por meio da rizicultura. Foram gerados dois cenários para aplicação de agrotóxico na área da rizicultura: solúvel em água e dissolvido no sedimento, padronizando a quantidade de agrotóxico aplicado no arroz, conforme indicações do fabricante em diferentes períodos. Durante os anos de 2013 a 2014, foram feitas 12 campanhas de monitoramento para avaliar a contaminação por diferentes agrotóxicos nas águas superficiais do rio Betume. Foi constatada a presença dos fungicidas, tebuconazole e tetrabuconazole e do carrapaticida clorpirifós. Desta forma, buscou-se através do ArcSWAT gerar cenário, com o agrotóxico solúvel em água. Com o resultado constatou-se a presença de concentração do Tebuconazole solúvel na água, mais atenuante entre os dados simulados e observados, isto pode ser explicado pela sua maior solubilidade em água e aplicação mais frequente, deste princípio ativo, pelos produtores, no combate a praga do Brusone.

Palavras-chave: SWAT, pesticidas, perimetros irrigados e monitoramento ambiental.
\end{abstract}

The use and occupation of land in flood plains in the Betume River basin has been causing serious environmental impacts such as: soil and water contamination by pesticides from agriculture and livestock. The environmental modelling is a useful tool in the management and handling of a hydrographical basin, allowing to predict the different impacts of human activities on water and soil. The SWAT (Soil and Water Assessment Tool) model allows evaluating impacts caused by changes in land use on the hydrological processes and the dynamics of pesticides in a watershed. This study aims to simulate the pesticide contamination potential in the Betume River, through the rice growing. Two Scenarios were generated for the application of pesticide in the rice-growing area: soluble in water and dissolved in sediment, which was a pattern to the quantity of pesticide applied to rice, according to the producer's indication in different periods. From 2013 to 2014, 12 campaigns were done in order to analyse the quality of pesticides in the Betume Riversurface. It was noticed the presence of fungicides, tebuconazole and tetrabuconazole and chlorpyrifos. This is why it was sought to generate the scenario through ArcSWAT, with soluble pesticide in water. The result showed concentration of Tebuconazole soluble in water, more attenuating between the simulated and observed data, and this can be explained by its greater solubility in water and the more frequent application of this active principle, by the producers, in the combat of rice blast plague.

Keywords: SWAT, pesticide, irrigated perimeter and environmental monitoring.

\section{INTRODUCTION}

The diffuse pollution sources generate the greatest environmental problems found in agricultural regions. Therefore, knowing the causes of pollution of the water resources and their impact on the environment is important for the management of these watersheds. The environmental modelling 
is an important tool to identify and analyze the interferences on the changes of the physical, chemical and microbiological processes occurring in geographically delimited environment.

Thus, the SWAT model has shown efficiency in evaluation studies of water resources and problems of diffuse sources of pollution in different environmental conditions and scales worldwide [1]. According to Neitsch et al. (2011) [2] the SWAT model performs hydrological simulations in the watershed, dividing the water cycle in two phases, land and water. In the terrestrial phase, it controls the amount of water and sediment loads, nutrients and pesticides that reach the main channel. In the aquatic phase, it relates to the movement of water, sediment and other water vents of the watershed [3].

The main tributaries of the São Francisco River have some environmental impacts that must be disclosed as the nutritional enrichment of water bodies that run through plantation areas, especially nitrogen and phosphorus contamination of water bodies with pesticides [4].

During the evaluation campaign in the Lower São Francisco, the focus was on the main riverbed, with emphasis on the riverbanks. In Propriá region, one can have a perception of irrigated areas and the various problems that characterize the flooded rice irrigation, including: problems in water quality in and out of the perimeters, excessive use of pesticides, pest and diseases attack, indebtedness of producers and irregularity in rice production [5].

Given these facts, the change in the water dynamics of the Betume River, together with the dry periods, resulted in impacts of economic, social and environmental dimensions, where the worst hit has been the local population, in irrigated areas and fishermen. As a result, a reduction in water quality by siltation has been observed, as well as changes in marginal area and the presence of underwater vegetation [6].

Thus arises the need for the monitoring of water sources with the use of environmental modelling systems, which can contribute to the understanding of natural resource degradation processes, as well as in the design of corrective measures to evaluate and implement social benefits with minimal environmental damage.

For this reason, it is necessary to improve the monitoring of the irrigated area of the Betume River by its size and importance in the development of this region. Therefore, this study aimed to simulate the potential pesticide contamination in the Betume River, through the rice cultivation and drainage systems that may influence environmental sustainability.

\section{MATERIAL AND METHODS}

This work was performed on the Betume River (Figure 1), located between the UTM coordinates 24L 765470 and 8850015 in the Ilha das Flores municipalities, Pacatuba and Neópolis. The irrigated area of the Betume has an irrigable area of 2.860 ha, with a concentration of 764 producers and located downstream of the city of Neópolis. The monitoring point was the station-3, Betume River (UTM 24L 763967; 8848187). 


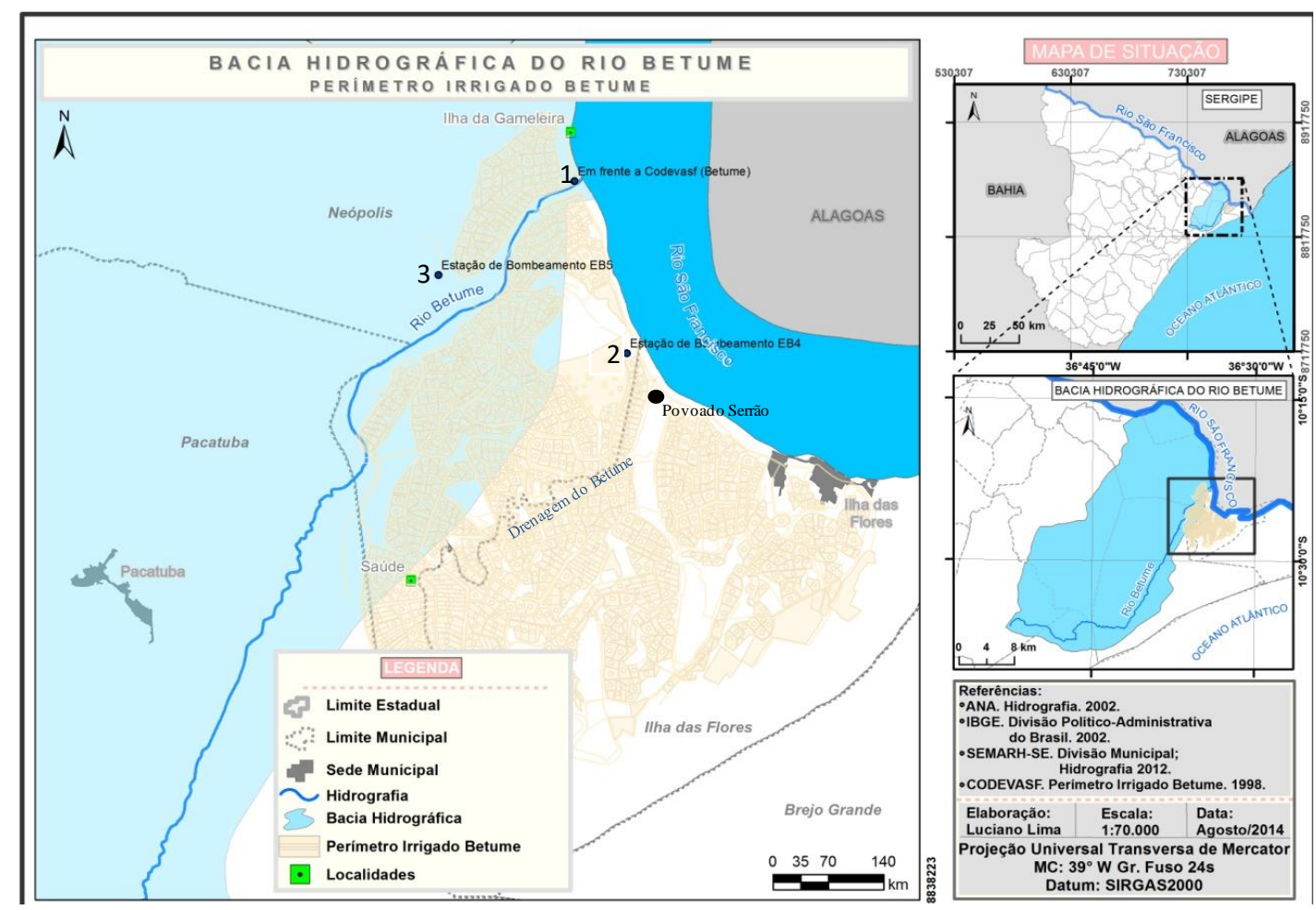

Figure 1: Location of Betume Irrigated Perimeter, Sergipe

The predominant farming in irrigated area is rice growing. The first processing plant went into operation in March 1985, generating positive impacts, not only by raising the income of the farmer, who started to get the minimum price determined by the government, but also an improvement the product classification criteria. There is predominance in rice production, practiced around the perimeter, having 1.512 ha of cultivation area in 2014. Since there is no business lots on the perimeter, only families, it is estimated to generate 1,500 direct jobs and 2.200 indirect jobs with an estimated production of 12.891 tons of food in 2014 [7]. The perimeter has a channel formed by four stations, which pump drainage water as well as replacement for the Betume and / or San Francisco Rivers. A channel was built so that drainage water recirculates the perimeter during the production of rice through pumping stations BSs 01, 07, 08, 09.

\subsection{Data collect}

Sampling points of conventional weather stations were provided by the National Institute of Meteorology (INMET) to Propriá (24L 736626; 8870574) and Pão de Açucar (24L 672215; 8921824); by the National Institute for Space Research (INPE) to Japaratuba (24L 724,579; $8,846,893$ ) and Neópolis (24L 762 676; 8836453). To Propriá station we obtained the daily rainfall data, solar radiation, maximum and minimum temperature, wind speed, humidity, while other stations obtained daily data of rainfall. The period was from January 1999 to December 2014, (16 years).

As for pesticides, it was necessary to identify the active ingredients most used in the Betume irrigated perimeter region. Through interviews with irrigators and farmers, as well as in pesticide sales outlets in the region of Aracaju, Propriá and Neópolis. In addition, water was collected from the Betume River, Pumping-EB5 Station, coordinates (24L 763 967; 8848187) from March 2013 to December 2014, with bimonthly campaigns, totaling 12 samples, on the surface layer of the river. Water samples were packed and sent to the laboratory of the Pernambuco Institute of Technology (ITEP), and analyzed by the multi-residue method using liquid-liquid extraction, quantification was performed on a gas chromatograph with electron capture detectors and liquid chromatograph [8]. 
The soil data were collected at coordinates $(24 \mathrm{~L} 763,968 ; 884,818)$ and $(24 \mathrm{~L} 765,977$; $8,849,056$ ), and other information were supplemented by literature soil pedology [9]. Hydrological data "flow" were collected from the Hydrological Information System (HIDROWEB) from September / 2012 to September / 2014 Alagamar village Station (49744000 code) in the Betume River at coordinates (24L 759 643; 8841702). Among the information required for the use of SWAT, there is the need to seek a historical series of the Betume River flow. The HIDROWEB site supplied the shares (water level). To calculate the flow through shares provided by HIDROWEB, we used the measured values relating to the shares and their flow to the section of the Betume River.

\subsection{Hydrosedimentological modeling}

The SWAT is a mathematical model that allows spatially simulate a watershed with complex mosaic of different uses between them, cover and soil types [10]. The model consists of the following elements: climate, hydrology, plant growth, soil, sediment, nutrients and pesticides, management and irrigation [11]. Tabular data for the climate (rainfall, minimum and maximum air temperature, solar radiation, wind speed and relative humidity) are also required. For this, data from the Meteorological Station of Propriá were compiled in the parameters to be used by WXGEN shown in Table 1.

The SWAT model used the maps of soil types and land use and land cover, both of which were obtained through the Secretary of Water Resources of Sergipe - SRH [12]. From these combinations, one can define the hydrological response units (HRU) for each sub-basin generated in the discretization process. This division enables the model to reflect the differences in hydrological processes, depending on the different characteristics of HRUs. Each sub-basin may contain one or more HRUs. The choice depends on the representation of each unit in the sub-basin and the level of detail required in the variable final answer.

The design of the basin was made through the river system generated based on digital terrain model and defined contribution area, resulting in 26 sub-basins (Figure 2), with a minimum contribution of an area of 500 ha. To avoid confusion, we adopted the term "sub-basin" for the divisions generated by the discretization of the study area. 192 HRUs were defined in the basin under study, for which independent parameterization were generated

In order to perform calibration and validation of hydrological modeling of the Betume River, SWAT-CUP computer program was used, based on the algorithm "SUFI-2", since it has been recommended because of its data processing efficiency [13,14].

The SWAT-CUP integrates various calibration and uncertainty analysis procedures for SWAT in an easy to handle interface; provides a faster way to make the time-consuming calibration operations and standardize calibration steps; adds functionality to the calibration, such as charting results and comparing the calibrated data [15].

At the end of automatic calibration, parameters of performance values, culminating in a better match for the coefficient of Nash -Sutcllife (NSE), the coefficient of determination $\left(\mathrm{R}^{2}\right)$ percentage trend (PBIAS), and the pattern standard average error, (RSR) based on literature review can be found in Table 2. 
Table 1: Description of climatic parameters required for the creation of statistical parameters of the weather station

\begin{tabular}{|c|c|c|}
\hline Parameter & Description & Unit \\
\hline WLATITUDE & Weather station latitude & degrees \\
\hline WLONGITUDE & Weather station longitude & degrees \\
\hline WELEV & Weather station height & $\mathrm{m}$ \\
\hline RAIN_YRS & $\begin{array}{l}\text { The number of years of monthly rainfall maximum data } 0.5 \mathrm{~h} \\
\text { used to define RAIN_HHMAX }\end{array}$ & -- \\
\hline TMPMX & Average maximum daily temperature in the month & ${ }^{\circ} \mathrm{C}$ \\
\hline TMPMN & Average minimum daily temperature in the month & ${ }^{\circ} \mathrm{C}$ \\
\hline TMPSTDMX & $\begin{array}{l}\text { Standard deviation of daily maximum temperature in the } \\
\text { month. }\end{array}$ & ${ }^{\circ} \mathrm{C}$ \\
\hline TMPSTDMN & $\begin{array}{l}\text { Standard deviation of daily minimum temperature in the } \\
\text { month. }\end{array}$ & ${ }^{\circ} \mathrm{C}$ \\
\hline РСРММ & Avarage total rainfall in the month & $\mathrm{mm}$ \\
\hline PCPSTD & Standard deviation of daily precipitation in the month & mm.day ${ }^{-1}$ \\
\hline PCPSKW & Skew coefficient for daily precipitation in the month & -- \\
\hline PR_W(1) & Probability of a wet day followed by a dry day in the month & -- \\
\hline PR_W(2) & $\begin{array}{l}\text { Probability of wet day followed by another wet day in the } \\
\text { month }\end{array}$ & -- \\
\hline PCPD & $\begin{array}{l}\text { Average of the average number of days with precipitation in } \\
\text { the month }\end{array}$ & -- \\
\hline RAINHHMX & $\begin{array}{l}\text { maximum rainfall of } 0.5 \mathrm{~h} \text { in the registration period in the } \\
\text { month }\end{array}$ & $\mathrm{mm}$ \\
\hline SOLARAV & Average daily solar radiation in the month & $\begin{array}{l}\text { MJ.m- } \\
{ }^{2} \cdot \text { day }^{-1}\end{array}$ \\
\hline DEWPT & Average daily dew point temperature in the month & ${ }^{\circ} \mathrm{C}$ \\
\hline WNDAV & Average daily wind speed in the month & $\mathrm{m} \cdot \mathrm{s}^{-1}$ \\
\hline
\end{tabular}

Source: Silva, 2013 [9] 


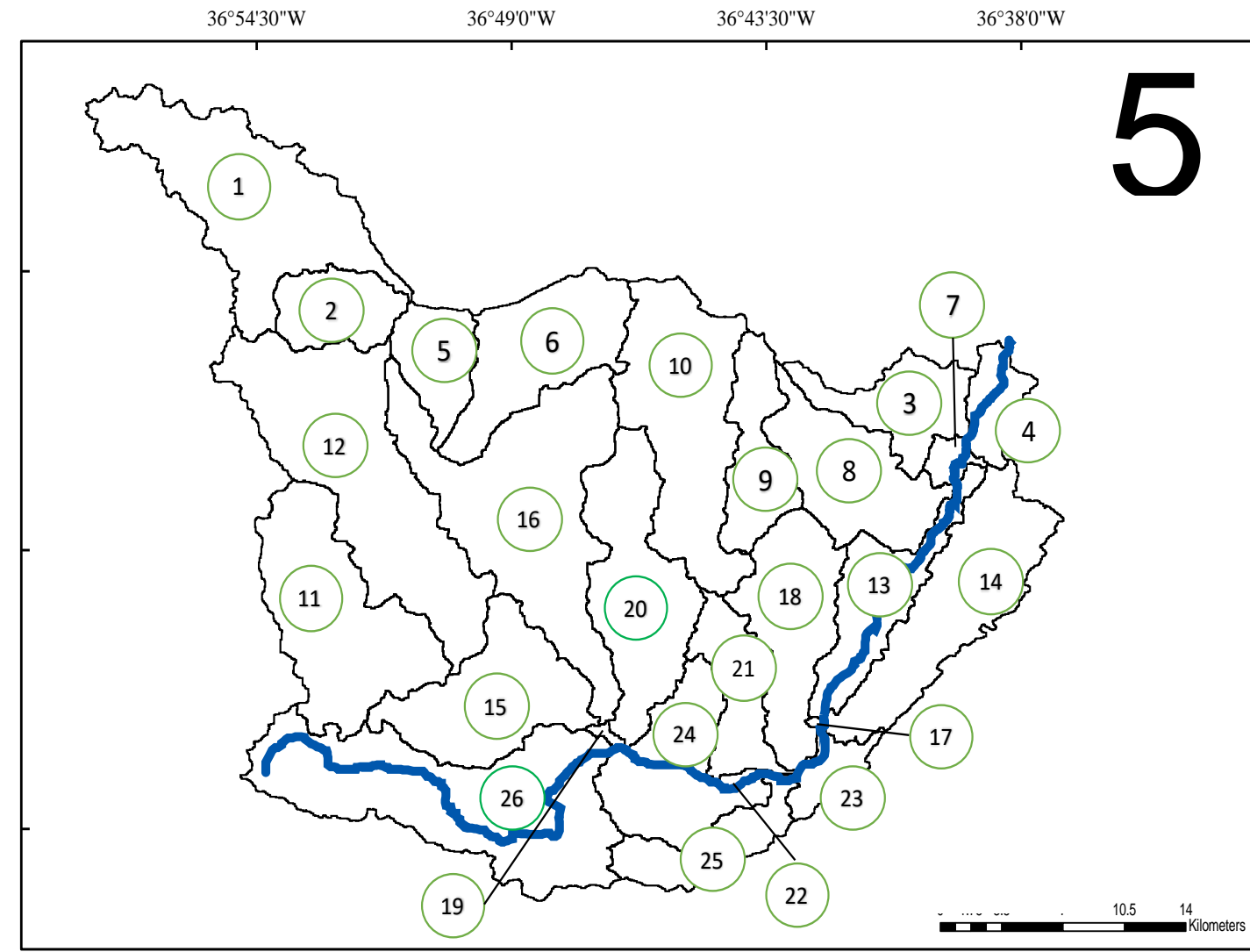

Figure 2: Distribution map of the hydrographic sub-basins of the Betume River

Table 2: Performance Assessment Criteria for hydrological models and their ratings

\begin{tabular}{|c|c|c|c|}
\hline Statistic & Value & $\begin{array}{l}\text { Performance } \\
\text { classification }\end{array}$ & References \\
\hline \multirow{5}{*}{ NSE } & $0,75<\mathrm{NSE} \leq 1,00$ & Very Good & Moriasi et al., 2007 [16] \\
\hline & $0,65<\mathrm{NSE} \leq 0,75$ & Good & Boskidis et al., 2012 [17] \\
\hline & $0,50<\mathrm{NSE} \leq 0,65$ & Satisfactory & \multirow{2}{*}{ Green e van Griensven, 2008 [18] } \\
\hline & $0,4<\mathrm{NSE} \leq 0,50$ & Acceptable & \\
\hline & $\mathrm{NSE} \leq 0,4$ & Dissatisfactory & Green et al, 2006 [19] \\
\hline $\mathrm{R}^{2}$ & $\mathrm{R}^{2}>0,5$ & Satisfactory & Green e van Griensven, 2008 [18] \\
\hline \multirow{4}{*}{ PBIAS (flow) } & PBIAS $< \pm 10$ & Very Good & \multirow{4}{*}{ Moriasi et al., 2007 [16] } \\
\hline & $\pm 1 \leq \mathrm{PBIAS}< \pm 15$ & Good & \\
\hline & $\pm 15 \leq$ PBIAS $< \pm 25$ & Satisfactory & \\
\hline & PBIAS $\geq \pm 25$ & Dissatisfactory & \\
\hline \multirow{4}{*}{ RSR } & $0,00 \leq \mathrm{RSR} \leq 0,50$ & Very Good & \multirow{4}{*}{ Moriasi et al., 2007 [16] } \\
\hline & $0,50<\mathrm{RSR} \leq 0,60$ & Good & \\
\hline & $0,60<\mathrm{RSR} \leq 0,70$ & Satisfactory & \\
\hline & $\mathrm{RSR}>0,70$ & Dissatisfactory & \\
\hline
\end{tabular}

The sensitivity analysis was performed by SWAT-CUP which identified the most influential parameters in the flow, accounting for 7 parameters. This process was carried out by changing the value of a parameter at a time for each simulation run, and evaluating the model response with respect to the measured data to provide a classification of these parameters, according to the degree of sensitivity to the response of this model. 
As the initial values of parameters CN2, ALPHA_BF, GW_DELAY, GWQMN, SOL_AWC, CH_N2 and HRU_SLP are determined from basin characteristics reported in thematic maps inserted to run the model. The method was indicated as shown in Table 3 for values within the interval established for the desired setting, i.e., the initial value of the parameter is adjusted on the basis of percentage changes. The $\mathrm{CN} 2$, for example, might be reduced by $20 \%(-0.2)$ and increased by $20 \%(0.2)$.

Table 3. Parameters and intervals of parameters used in SWAT-CUP.

\begin{tabular}{|c|c|c|c|c|}
\hline \multirow{2}{*}{ Parameter } & \multirow{2}{*}{ Description / Function } & \multirow{2}{*}{ Method } & \multicolumn{2}{|c|}{ Interval } \\
\hline & & & Min & Max \\
\hline $\mathrm{CN} 2$ & $\begin{array}{l}\text { Curve number in condition II: This parameter is } \\
\text { important in the calculation of runoff when using the } \\
\text { SCS Curve Number method for its calculation. The } \\
\text { CN is a dimensionless number and is obtained } \\
\text { depending on the permeability of the soil, and the use } \\
\text { of the antecedent condition moisture in the soil. } \\
\text { Thus, the runoff values in the basin are proportional } \\
\text { to the CN parameter. }\end{array}$ & Multiply & -0.2 & 0.2 \\
\hline ALPHA_BF & $\begin{array}{l}\text { Recession constant base flow: this parameter is a } \\
\text { direct indicator of the groundwater flow response to } \\
\text { changes in recharge. The higher the value of this } \\
\text { parameter the greater is the aquifer recharge and the } \\
\text { lower is the base flow. Values range from } 0.1 \text { to } 0.3 \\
\text { for soils with a slow response to reload and } 0.9 \text { to } 1.0 \\
\text { for soils with a quick response. }\end{array}$ & Equalize & 0 & 1 \\
\hline GW_DELAY & $\begin{array}{l}\text { Time interval for the aquifer recharge: This } \\
\text { parameter is important in the calculation of aquifer } \\
\text { recharge and is dependent on the geological } \\
\text { formation. The GW_DELAY is inversely } \\
\text { proportional to the recharge. }\end{array}$ & Equalize & 30 & 450 \\
\hline GWQMN & $\begin{array}{l}\text { Water Depth limit of the shallow aquifer required for } \\
\text { the return flow to occur: the higher the value of this } \\
\text { parameter the greater portion of the base flow is } \\
\text { retarded. That is, for low values of this parameter, } \\
\text { more base flow is made and a high river flow. The } \\
\text { groundwater flow to the channel is permitted only if } \\
\text { the water depth in the shallow aquifer is equal to or } \\
\text { greater than the GWQMN. }\end{array}$ & Equalize & 0 & 2 \\
\hline SOL_AWC & $\begin{array}{l}\text { Water capacity available in the soil: This parameter } \\
\text { is important in the process of moving the water in the } \\
\text { soil and is used to calculate the water content in the } \\
\text { soil available for vegetation. It is given by the } \\
\text { difference between the field capacity and the wilting } \\
\text { point. }\end{array}$ & Multiply & -0.2 & 0.4 \\
\hline CH_N2 & $\begin{array}{l}\text { Manning coefficient for the main channel: influences } \\
\text { the speed of the water in the soil and consequently, } \\
\text { the concentration time }\end{array}$ & Equalize & 0 & 0.3 \\
\hline HRU_SLP & $\begin{array}{l}\text { Average slope: Increasing it means increasing the } \\
\text { lateral flow and decrease the time of concentration } \\
\text { of the basin }\end{array}$ & Multiply & 0 & 0.2 \\
\hline
\end{tabular}

This model can simulate the movement of pesticides through runoff, soil profile, by infiltration of groundwater, the amount of pesticide applied, which is under direct influence of the solubility, half-life and the absorption coefficient. In this sense, the authors have been using this tool to simulate the runoff of pesticides in water and / or sediment for different scenarios [20,2].

Once the parameter sensitivity analysis is completed, the data is applied in ArcSWAT. The value $\mathrm{p}$ ( $\mathrm{p}$-Value) determines the significance of sensitivity where near zero values have greater significance [21], or in SUFI-2 method the ALPHA_BF parameter was the most significant for 
modeling, and is a direct indicator of the groundwater flow response to changes in recharge. The higher the value of this parameter, the greater the lower aquifer recharge and base flow. The importance of ALPHA_BF parameter is explained by the fact that the concentrations of the variables of the water quality during low flow periods are dependent on the estimated flow rate, thus the concentrations may be higher in periods of drought. During these periods, the flow depends on groundwater contribution, which in turn has a strong dependence on ALPHA_BF parameter [22].

With the parameters defined in Swat-Cup, we return to the ArcSWAT and change the values on the "Manual Calibration Helper," adding, matching or replacing the values as parameters (Table 3.4). In the first method, the initial value of the parameter is changed by adding a value. The second method is to multiply the initial value of the parameter by a value (in percentage). In the latter method, the initial value of the parameter is replaced by another value [22].

On the analysis of research processes, we also made the analysis of pesticide contamination potential using the Groundwater Ubiquity Score index (GUS), the criteria of the Environmental Protection Agency (EPA) and the GOSS method [6]. These methods allow evaluating the possibility of risk of groundwater and surface water contamination by means of information about the active ingredients and their physicochemical properties.

With tabulated data we can generate two scenarios: application of pesticides: (1) water-soluble (2) dissolved in the sediment. In addition, the following information were standardized: For Tebuconazole, in November, with one application of $4 \mathrm{~g} \cdot \mathrm{ha}^{-1}$; for Tetraconazole, in August, with 1 application of $40 \mathrm{~g} \cdot \mathrm{ha}^{-1}$; Chlorpyrifos for the month of March, with the first application of $480 \mathrm{~g} . \mathrm{ha}^{-}$ ${ }^{1}$, thereby enabling to analyze the pesticide behavior in rice growing areas of water and sediments.

\section{RESULTS AND DISCUSSION}

The results of the water model calibration can be seen in Figure 3.5, so it is apparent that the simulated flow in SWAT of the Betume River correlate with the measured flow rate, with 95\% probability. The performance evaluation criteria from the hydrological model can be assessed in indicating good calibration, according to the hydrograph in Figure 3, shows peak values of the simulated flow slightly underestimated from August / 2013 to March / 2014, as in June, which is the rainy season the peak flows were slightly overestimated. However, the overall trend of the simulated water production for the period was well represented by the model. As for times of recession, one can observe a satisfactory adjustment from SWAT, which makes it effective in the simulation of minimum flows, as also reported by Andrade, Melo and Beskow (2013) [23].

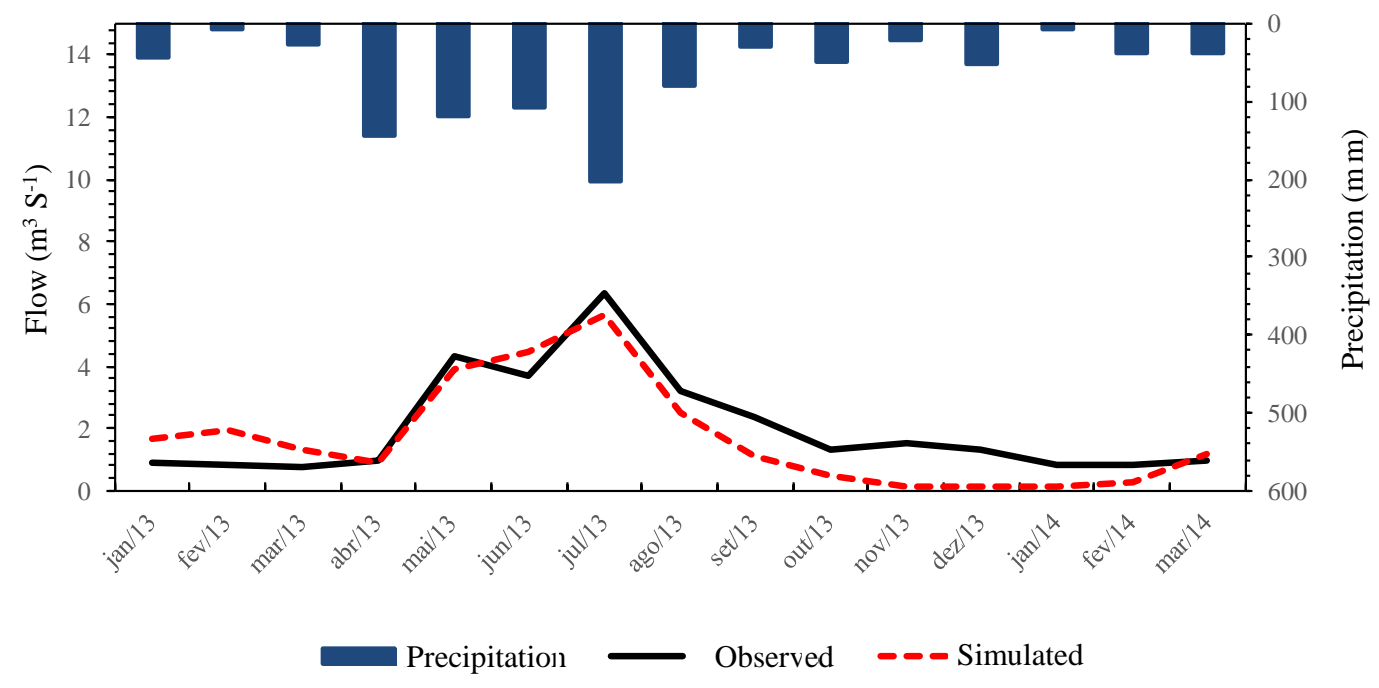

Figure 3: Hydrograph of monthly flow calibration related to the period from January / 2013 to March /2014 
Model validation was conducted for the period from April 2014 to August 2015. During the validation (Figure 4), one realizes that the data flow peaks observed and simulated during the observed period did not coincide, but there was a trend similarity to the minimum flows. The results of the validation for PBIAS and R2, were respectively 24.9 and 0.63 considered satisfactory, so it can be said that the model is able to describe the hydrological processes of the Betume River even with little hydrological information.

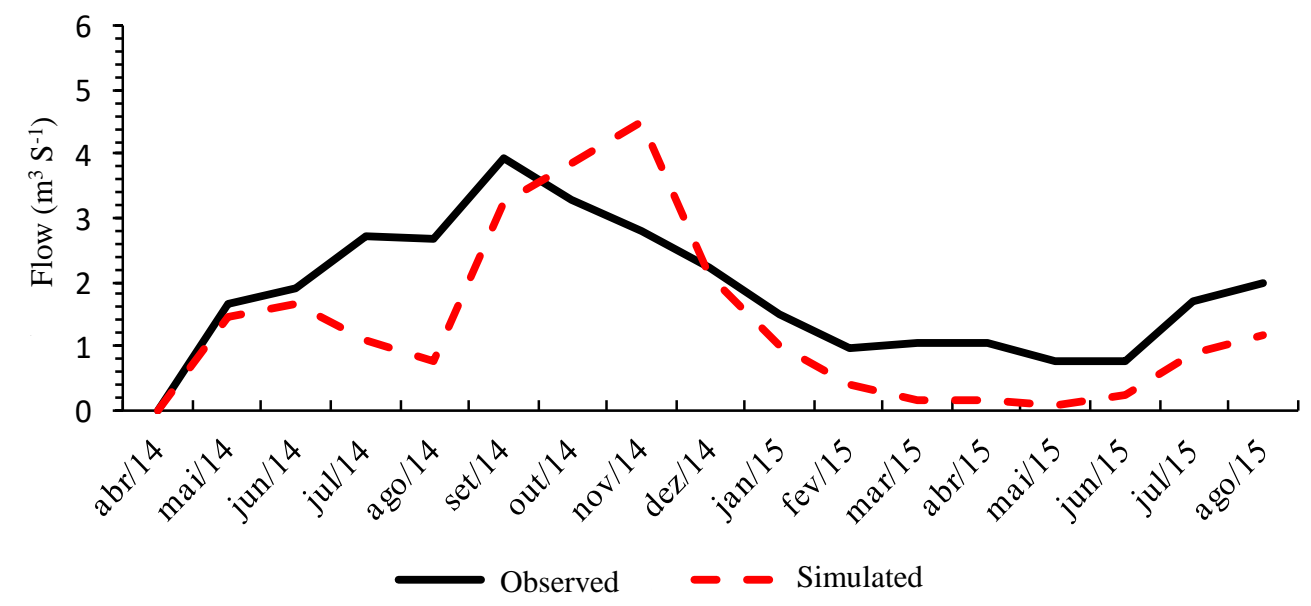

Figure 4: Hydrograph of monthly flow related to the validation from April / 2014 to August / 2015

Arnold et al. (2012) [24], bringing together 64 studies of world's largest representation with SWAT, indicated the most commonly used parameters in the calibration process. Regarding the runoff are CN2, AWC, ESCO, SURLAG, EPCO and OV_N; and as for the base flow are: ALPHA_BF, GW_DELAY, GW_REVAP, RCHARG_DP, GWQMN and REVAPMN. However, in this study, only 7 parameters from the observed and simulated hydrographs were obtained visually adequate results, among them were CN2, ALPHA_BF, GW_DELAY, GWQMN, SOL_AWC, CH_N2 and HRU_SLP.

The availability of historical data related to environmental parameters, hinders the development of field research and the application of mathematical models. As a result, the lack of historical data related to the concentration of pesticides in water and sediment, did not allow the model calibration for the Betume River. However, this fact does not preclude the study of spatial variability, because according to the forerunners of SWAT, the model can be applied in non-instrumented watersheds $[25,2,26]$, in this case, study is used to make inferences about the main producing areas. Compatible values were found in the Betume River, among the pesticide results observed through bimonthly monitoring and simulated water by SWAT.

The integration of data can generate scenarios by applying the pesticides Chlorpyrifos, Tebuconazole and Tetraconazole in the area of rice cultivation at different times. The simulated dose of pesticides was defined as the average dose of registered active ingredient, recommended and described on labels of commercial products used in the river basin and determined by Armas et al (2005)[27]. It is clear that much of the applied product does not reach the target.

The results obtained from the hydrological model SWAT for the dynamics of simulated pesticides in the Betume River basin, carried in water and sediments were distributed in Table 5 and Figure 5 and 6, with the irrigated perimeter of the rice culture, where the application of pesticides occurred.

Thus, it is observed that the presence of Tebuconazole presented more attenuating compared with other pesticides. This can be explained by their higher solubility in water, which indicates a tendency of the compound to be removed from the soil. However, high solubility, does not imply greater mobility in soil (Figure 5).

The sub-basin 21 showed the highest concentration for the three simulated pesticides, which may be related to soil type Neossolo. This feature has high regard macro/micro pores, given the high degree of rounding of quartz grains that compose it. This condition favors the fastest percolation of water, reflected by the high hydraulic conductivity of this soil (K) which, combined 
with its low clay content and low in organic matter, contribute to the intensification of the leaching process [28].

During the bimonthly water sampling, carried out from March 2013 to December 2014, three active principles used in agricultural practices of the irrigated perimeter Betume region were found: chlorpyrifos, tebuconazole and tetrabuconazole with their trade names Colosso, Nativo and Domark. The presence of these pesticides in the Betume River was detected in November 2013, March, October and December 2014. There were no concentration above the quantification limit (LQ): $0.03 \mu \mathrm{g} . \mathrm{L}-1$ in the other samples taken (table 4).

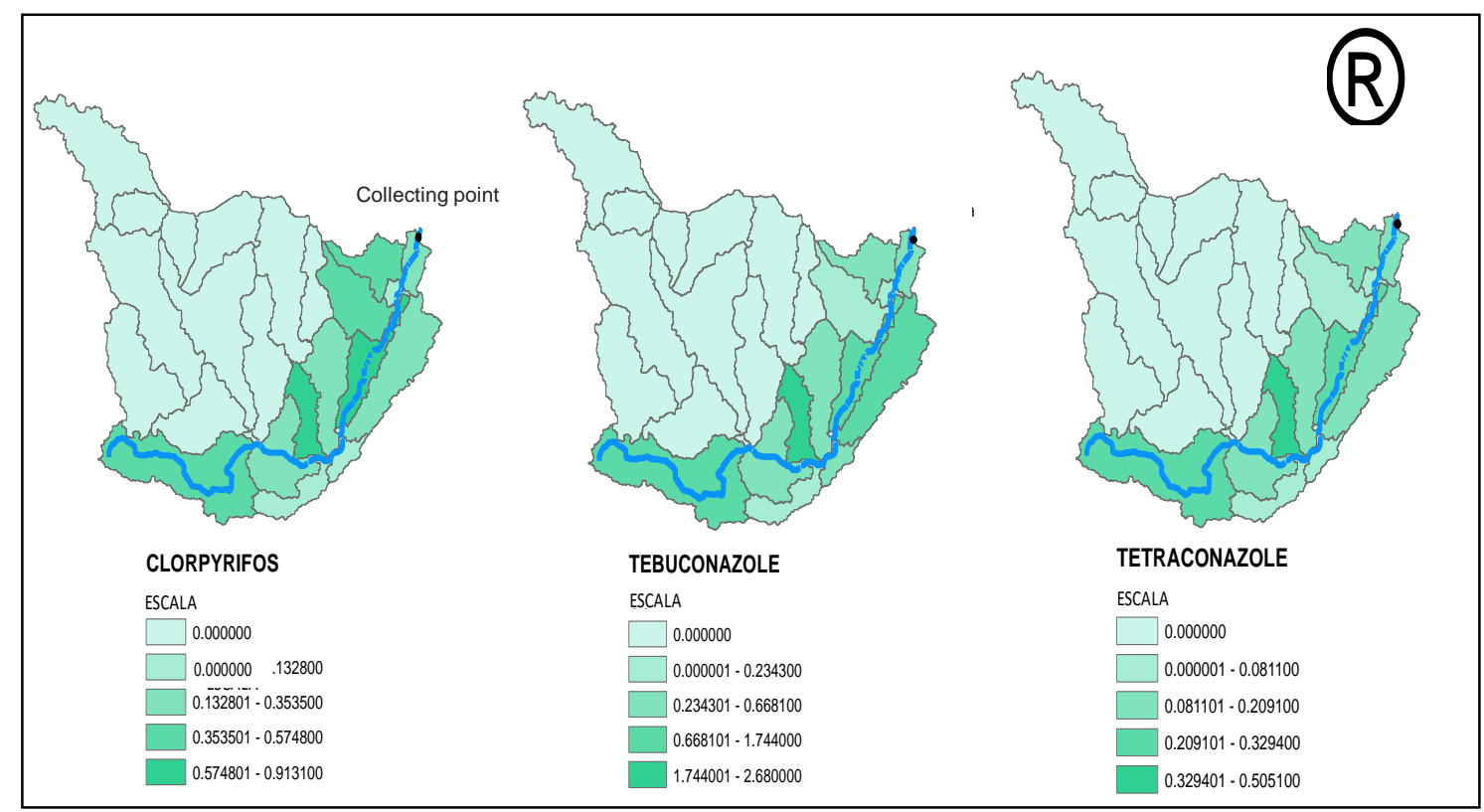

Figure 5: Behavior of pesticides in the Betume River and collection point $\left(\mu g . L^{-1}\right)$

Table 4: Concentration of Chlorpyrifos, Tebuconazole and Tetraconazole during the rainy and dry season in Betume River

\begin{tabular}{ccccc}
\hline Collection Date & $\begin{array}{c}\text { Monthly } \\
\text { Precipitation } \\
(\mathrm{mm})\end{array}$ & $\begin{array}{c}\text { Chlorpyrifos } \\
\left(\mu \mathrm{g} . \mathrm{L}^{-1}\right)\end{array}$ & $\begin{array}{c}\text { Betume River } \\
\text { Tebuconazole } \\
\left(\mu \mathrm{g} . \mathrm{L}^{-1}\right)\end{array}$ & $\begin{array}{c}\text { Tetraconazole } \\
\left(\mu \mathrm{g} . \mathrm{L}^{-1}\right)\end{array}$ \\
\hline $14 / 03 / 2013$ & 37.25 & $<\mathrm{DL}$ & $<\mathrm{DL}$ & $<\mathrm{DL}$ \\
$27 / 05 / 2013$ & 200.5 & $<\mathrm{DL}$ & $<\mathrm{DL}$ & $<\mathrm{DL}$ \\
$25 / 07 / 2013$ & 202.9 & $<\mathrm{DL}$ & $<\mathrm{DL}$ & $<\mathrm{DL}$ \\
$23 / 09 / 2013$ & 48.3 & $<\mathrm{DL}$ & $<\mathrm{LD}$ & $<\mathrm{DL}$ \\
$20 / 11 / 2013$ & 93.75 & $<\mathrm{DL}$ & 0.48 & $<\mathrm{DL}$ \\
$28 / 01 / 2014$ & 9.75 & $<\mathrm{DL}$ & $<\mathrm{DL}$ & $<\mathrm{DL}$ \\
$17 / 03 / 2014$ & 73 & 0.12 & $<\mathrm{DL}$ & $<\mathrm{DL}$ \\
$14 / 05 / 2014$ & 253.5 & $<\mathrm{DL}$ & $<\mathrm{DL}$ & $<\mathrm{DL}$ \\
$15 / 07 / 2014$ & 238.25 & $<\mathrm{DL}$ & $<\mathrm{DL}$ & $<\mathrm{DL}$ \\
$20 / 08 / 2014$ & 102.5 & $<\mathrm{DL}$ & $<\mathrm{DL}$ & $<\mathrm{DL}$ \\
$14 / 10 / 2014$ & 202.75 & $<\mathrm{DL}$ & 0.08 & $<\mathrm{DL}$ \\
$03 / 12 / 2014$ & 18.25 & $<\mathrm{DL}$ & 0.09 & 0.08 \\
\hline
\end{tabular}

Note: <DL - Value below the Detection Limit method.

Average monthly precipitation in the last 12 years (2003 a 2014) 
Comparing the observed data with the data collected, the pesticide Tebuconazole was detected more frequently and in greater concentration in this region. The Tebuconazole is a fungicide that fights Grain decay disease (Tilletiabarclayana), Rice Blast (Pyriculariagrisea) and Brown Stain (Bipolarisoryzae). Workers started using this pesticide to combat the blast disease. This is the causative agent of the disease Pyricularia grisea (Cooke) Sacc, which has the capacity to infect various grasses, including rice. The disease develops rapidly when there are appropriate conditions such as dew periods and associated with light rainfall, which keep moisture on the leaves [29].

The movement of pesticides in the water cycle also includes the handling of pesticides by sediment in aquatic biota of the springs. Studies have shown that sediments contaminated with persistent organic pollutants such as pesticides and organochlorines are real contaminations of water sources [30]. Thus, the simulation of Scenario 2 was made by applying the pesticides Chlorpyrifos, Tebuconazole and Tetraconazole in the area of rice cultivation at different times and identifying the behavior of the sediment (Figure 6).

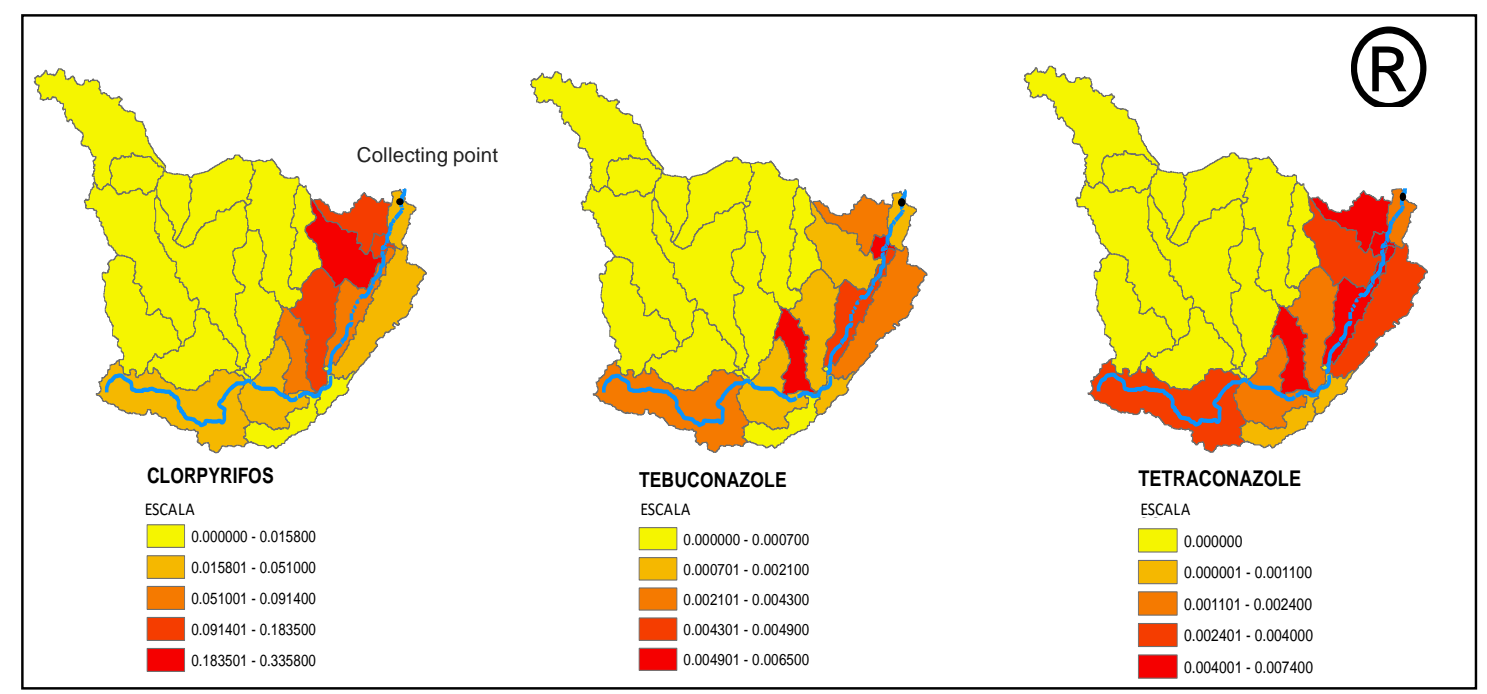

Figure 6: Behavior of pesticides on the Betume River sediment and collection point $\left(\mu g . L^{-1}\right)$

The concentration of pesticides in the sediment showed low values when compared to the movement in the water, this is due to their high mobility in water and lowsoil retention. Several authors have proven this fact by GOSS method and analysis in the field [31].

It is worth noting that the presence of Clorpifiros occurred in rice off season (February to May). At this time, it is common for some producers leave the cattle to feed in the fields of rice, after the grain harvest (rice straw). The trade name of this product is Collosso fighting the cattle tick, and is the active ingredient Chlorpyrifos.

However, it was not possible to make analysis of pesticides in sediment in the field, based on the lack of consistent data for adsorption / desorption of less persistent pesticides in sediments difficult to predict the behavior of these substances in this compartment. It is worth noting that some authors have identified the presence of Chlorpyrifos in sediments [32, 33, 34].

The Lambda-cyhalothrin pesticides, Mancozeb, Thiophanate-methyl, tricyclazole and Cypermethrin were not found during field measurements. Though they are used by farmers in rice crops at different times. The concentrations of the active ingredients that were leached in water, through simulation using the SWAT are described in Table 5.

The Lambda-cyhalothrin is an insecticide belonging to the chemical group of Piretroides. For GUS method, EPA is likely to leach, while Goss method, has low potential for transport in water [6]. Comparing the results in Table 3.6, it is observed that its concentration in water showed low values for superficial flow, with the sub-basin 13 having the highest concentration. This result may be related to half life (7 days), or solubility, before addition, compounds with low solubility in water tend to become strongly absorbed by the surface of clay and soil organic matter [35].

Another insecticide used in the region, would be the cypermethr in, which has a low mammalian toxicity, low environmental impact, is effective against a broad spectrum of insects, but improper 
use can have neural and cardio-toxic effects on vertebrates (Santos et al., 2007). The sub-basin 13 showed high value of pesticide concentration in water, because the area is composed of soil type Neosol, which provides greater leaching. This result is above the value recommended by the European Community, which allows maximum concentration of $0.1 \mathrm{ug} \mathrm{L}-1$ for any pesticide in water intended for human consumption [36].

Table 5: Pesticides concentration in the water for the SWAT modeling

\begin{tabular}{|c|c|c|c|c|c|}
\hline \multirow[b]{2}{*}{ Sub-basin } & \multicolumn{5}{|c|}{ PrincípiosAtivos } \\
\hline & $\begin{array}{c}\text { Lambda } \\
\text { cyhalothrin }\end{array}$ & Mancozeb & $\begin{array}{c}\text { Thiophanate- } \\
\text { methyl }\end{array}$ & Tricyclazole & Cypermethrin \\
\hline 1 & 0.0000 & 0.0000 & 0.0000 & 0.0000 & 0.0000 \\
\hline 2 & 0.0000 & 0.0000 & 0.0000 & 0.0000 & 0.0000 \\
\hline 3 & 0.0058 & 0.3302 & 0.0054 & 0.9943 & 40610 \\
\hline 4 & 0.0024 & 0.2146 & 0.0027 & 0.4304 & 25610 \\
\hline 5 & 0.0000 & 0.0000 & 0.0000 & 0.0000 & 0.0000 \\
\hline 6 & 0.0000 & 0.0000 & 0.0000 & 0.0000 & 0.0000 \\
\hline 7 & 0.0005 & 0.0466 & 0.0006 & 0.0892 & 0.5575 \\
\hline 8 & 0.0036 & 0.2875 & 0.0040 & 0.7680 & 35797 \\
\hline 9 & 0.0000 & 0.0000 & 0.0000 & 0.0000 & 0.0000 \\
\hline 10 & 0.0000 & 0.0000 & 0.0000 & 0.0000 & 0.0000 \\
\hline 11 & 0.0000 & 0.0000 & 0.0000 & 0.0000 & 0.0000 \\
\hline 12 & 0.0000 & 0.0000 & 0.0000 & 0.0000 & 0.0000 \\
\hline 13 & 0.0059 & 0.5638 & 0.0059 & 16640 & 57100 \\
\hline 14 & 0.0039 & 0.3425 & 0.0043 & 0.8245 & 41990 \\
\hline 15 & 0.0000 & 0.0000 & 0.0000 & 0.0000 & 0.0000 \\
\hline 16 & 0.0000 & 0.0000 & 0.0000 & 0.0000 & 0.0000 \\
\hline 17 & 0.0000 & 0.0000 & 0.0000 & 0.0000 & 0.0000 \\
\hline 18 & 0.0036 & 0.3617 & 0.0040 & 0.6379 & 36240 \\
\hline 19 & 0.0000 & 0.0000 & 0.0000 & 0.0000 & 0.0000 \\
\hline 20 & 0.0000 & 0.0000 & 0.0000 & 0.0000 & 0.0000 \\
\hline 21 & 0.0047 & 0.4958 & 0.0038 & 18790 & 36890 \\
\hline 22 & 0.0000 & 0.0000 & 0.0000 & 0.0000 & 0.0000 \\
\hline 23 & 0.0018 & 0.2360 & 0.0044 & 0.3926 & 23600 \\
\hline 24 & 0.0029 & 0.2346 & 0.0024 & 0.8937 & 32940 \\
\hline 25 & 0.0007 & 0.0739 & 0.0010 & 0.2505 & 0.8961 \\
\hline 26 & 0.0053 & 0.1276 & 0.0057 & 0.9450 & 53680 \\
\hline
\end{tabular}

The blast fungus found in the irrigated rice cultivation, can be countered by tricyclazole fungicide used to prevent the onset of this body. It belongs to the Benzothiazol chemical group which inhibits the melanin formation in fungi, then in the absence of melanin, inhibits the host plant holder [37]. Its concentration in water at sub-basin 21 presented intermediate value, as occurred with the GOSS method [6], which can be explained by the half-life in water (92 days), namely the time period required for degrading half the quantity initially applied to the environment.

Themancozeb fungicide containing manganese in its molecule, which is associated with damage to the central nervous system, such as parkinsonism syndrome reminiscent (Debbarh et al 2002, ZHOU et al 2004). In Table 5, the concentration showed low values, with greater representation in the sub-basin 13, due to the low solubility, ie, pesticide ability to dissolve in a standard amount of water. Likewise, thiophanate-methyl showed similarity in the results. With toxicological 
classification IV, considered high, and through the GOSS method, it has an average transport potential in the sediment and water [38].

Several health problems have been linked in recent decades, the international scientific literature, including those of the central nervous system, liver, kidney and cardio-respiratory diseases, among other manifestations of chronic exposure to these chemicals. Since there are no safety limits for the presence of pesticide residues in rainwater, it is impossible to measure the real impact of such via the deterioration of the environment, human health and biodiversity. Added to this is the fact that very little is known about the possible late effects that a multiple and continuous exposure to low doses of pesticides can bring to the health of these populations, especially the most vulnerable [39].

\section{CONCLUSIONS}

Calibration presented indices considered satisfactory for R2 parameters (0.79), NSE (0.73), PBIAS (14.7) and RSR 0.52 indicating a reality when comparing simulated and observed data for the Betume River flow.

The management of rice cultivation, by the process of irrigation by flooding and drainage of the crop, provided greater frequency and pesticide concentration in the Betume River, due to the low mobility in the water, the application of pesticides to combat rice blast and the high potential of being transported when dissolved in water.

The runoff favored contamination of surface waters by transporting pesticides adsorbed by sediment particles, to Clorpifiros ticks pesticide.

As for the movement of pesticides in water, the sub-basin 13 had higher concentrations, due to the soil type, Neossolo, which provides greater leaching. The tricyclazole and cypermethrin showed higher pesticide concentrations than can be explained by its solubility in water and low retention in the soil.

Evidence of human activities related to modifications of using the Betume river soil promoted changes in production and water quality as well as the increase of pesticides in sediments and in simulated water surface in the SWAT model.

\section{REFERÊNCIAS BIBLIOGRÁFICAS}

1. Gassman PW, Reyes MR, Green, CH, Arnold JG. The Soil and Water Assessment Tool: Historical development, applications, and future research directions. American Society of Agricultural and Biological Engineers. 2007;50(4):1211-1250.

2. Neitsch SL, Arnold JG, Kiniry JR, Williams JR. Soil and Water Assessment Tool: Theoretical Documentation - Version 2009. Texas Water Resources Institute Technical Report $\mathrm{N}^{\circ}$ 406. Temple: Agricultural Research Service (USDA) \& Texas Agricultural Experiment Station (Texas A\&M University); 2011. 647 p.

3. Garbossa LHP, Vasconcelos LRC, Lapa KR, Blainski E, Pinheiro A. The use and results of the Soil and Water Assessment Tool in Brazil: A review from 341999 until 2010. In: 2011 International SWAT Conference \& Workshops, Toledo Espanha. p. 1-27. 2011.

4. Aguiar Netto AO, Lucas AAT, Santos AGC, Almeida CAP. Água e ambiente no Baixo São Francisco Sergipano. In: AAT Lucas; AO Aguiar Netto. (Org.). Águas do São Francisco. 1ed. São Cristóvão: UFS, 2011; p. 15-32.

5. Nascimento MC, Ribeiro CEJ, Aguiar Netto AO. Relatório técnico da campanha de avaliação das mudanças socioambientais decorrentes da regularização das vazões no baixo Rio São Francisco, Comitê da Bacia Hidrográfica do rio São Francisco Alagoas, 2013.

6. Britto FB, Silva TMM, Vasco NA, Aguiar Netto AO, Carvalho MC. Avaliação do Risco de Contaminação Hídrica por Agrotóxicos no Perímetro Irrigado Betume no Baixo Rio São Francisco. Rev Bras Agric Irrigada. 2015;9(3):158-170, doi:10.7127/RBAI.V9N300301.

7. Codevasf. Companhia de Desenvolvimento dos Vales do São Francisco e do Parnaíba. Perímetros Irrigados Betume. Aracaju, SE, 2015. Acesso em 10 de julho de 2015. Disponível em http://www.codevasf.gov.br/principal/perimetros-irrigados/ elenco-de-projetos/betume. 
8. Peixe TS, Nascimento ES, Rosa HVD. Determinação de fenol urinário por cromatografia em fase gasosa em trabalhadores que utilizam resinas fenólicas em fundições, Rev Bras Ciênc Farmac. 2006;42(2):279287, https://dx.doi.org/10.1590/S1516-93322006000200014.

9. Silva MG. Modelagem Ambiental na Bacia hidrográfica do Rio Poxim-Açu/SE e suas Relações Antrópicas Tese submetida ao Programa de Pós-Graduação em Desenvolvimento e Meio Ambiente na Universidade Federal de Sergipe, São Cristóvão, 2013.

10. Lopes NHY, Kobiyama M. Análise do Equilíbrio Hidrossedimentológico em uma Microbacia Experimental com o Modelo SWAT e as Características Geomorfológicas. In Anais do VII Simpósio Nacional De Geomorfologia; I Encontro Latino-Americano de Geomorfologia, Belo Horizonte, 2008.

11. Durães MF. Caracterização e avaliação do estresse hidrológico da bacia do rio Paraopeba, por meio de simulação chuva-vazão de cenários atuais e prospectivos de ocupação e uso do solo utilizando um modelo hidrológico distribuído. Dissertação. Programa de Pós-Graduação em Saneamento, Meio Ambiente e Recursos Hídricos - Universidade Federal de Minas Gerais, Belo Horizonte, 2010.

12. Sergipe. SRH - Superintendência de Recursos Hídricos. Atlas digital sobre os Recursos Hídricos de Sergipe. ARACAJU: SEPLANTEC-SRH, CD-ROM. 2012.

13. Schuola J, Abbaspour KC, Srinivasan R, Yang H. Estimation of freshwater availability in the West African sub-continent using the SWAT hydrologic model. J Hydrol. 2008;352(1-2):30-49, doi:10.1016/j.jhydrol.2009.05.016.

14. Faramarzi, M, Abbaspour KC, Schulin R, Yang H. Modelling blue and green water resources availability in Iran. Hydrol Proc. 2009;23(3):486-501, doi:10.1002/hyp.7160.

15. Veiga AM. Calibração Hidrossedimentológica do Modelo Swat na Bacia Hidrográfica no Córrego Samambaia, Goiânia - GO. Dissertação. Programa de Pós-Graduação em Engenharia do Meio Ambiente da Universidade Federal de Goiás Goiânia, 2014.

16. Moriasi DN, Arnold JG, Van Liew MW, Bingner RL, Harmel RD, Veithet TL. Model evaluation guidelines for systematic quantification of accuracy in watershed simulations. Am Soc Agr Biol Eng. 2007;50(3):885-900, doi:10.13031/2013.23153

17. Boskidis I, Gikas GD, Sylaios GK, Tsihrintzis VA. Hydrologic and water quality modeling of lower Nestos River basin. Water Resour Manag. 2012;26:3023-3051.

18. Green CH, Van Griensven A. Autocalibration in hydrologic modeling: Using SWAT2005 in small-scale watersheds. Environm Modelling\& Software. 2008;23:422-434.

19. Green CH, Tomer MD, Luzio M DI, Arnold JG. Hydrologic evaluation of the soil and water assessment tool for a large tile-drained watershed in Iowa. Am Soc Agric Biol Eng. 2006;49(2):413-422.

20. Arnold JG, Srinivasan R, Muttiah RS, Williams JR. Large area hydrologic modeling and assessment. Part I: Model development. J Am Water Res Assoc. 1998;34(1):73-89.

21. Abbaspour KC. SWAT-CUP2009: SWAT Calibration and Uncertainty Programs - a user manual. Department of Systems Analysis, Integrated Assessment and Modelling (SIAM), Eawag, Swiss Federal Institute of Aquatic Science and Technology, Duebendorf, Switzerland, 95 p. 2011.

22. Van Griensven A, Meixnera T, Grunwald S, Bishop T, Diluzio M, Srinivasan R. A global sensitivity analysis tool for the parameters of multivariable catchment models. J Hydrol. 2006;324(1-4):10-23, doi:10.1016/j.jhydrol.2005.09.008.

23. Andrade MA, Mello CR, Beskow S. Simulação hidrológica em uma bacia hidrográfica representativa dos Latossolos na região Alto Rio Grande, MG. Rev Bras Eng Agríc Amb. 2013;17(1):69-76, doi:10.1590/S1415-43662013000100010.

24. Arnold JG, Fohrer N. Swat 2000: current capabilities and research opportunities in applied watershed modelling. Hydrol Process. 2005;19(3):563-572, doi:10.1002/hyp.5611.

25. Arnold JG, Moriasi DN, Gassman PW, Abbaspour KC, White MJ, Srinivasan, R, Santhi C, Harmel RD, Van Griensven A, Van Liew MW, Kannan N, Jha MK. SWAT: Model Use, Calibration, and Validation. Transactions of the ASABE. 2012;55(4):1491-1508, doi:10.13031/2013.42256.

26. Uzeika T. Use of the SWAT model for hydro-sedimentologic simulation in a small rural watershed. Rev Brasil Ciência Solo. 2012;36(2):557-565, doi:10.1590/S0100-06832012000200025.

27. Armas ED, Monteiro RTR, Amâncio VA, Correa RML, Guercio MA. Uso de pesticidas em cana-deaçúcar na bacia do rio Corumbataí e risco de contaminação de poluição hídrica. Química Nova. 2005; 28(6):975-982, doi:10.1590/S0100-40422005000600008.

28. Gomes MAF, Pereira AS, Queiroz SCN, Ferracini VL, Jardim ICSF, Paula MM, Diogo A. Movimento do Herbicida Imazetapir em um Neossolo Quartzarênico Típico e em um Latossolo de Textura Média das Nascentes do Rio Araguaia, Município de Mineiros (GO). Pesticidas: Rev Ecotoxicol Meio Ambiente. 2008;18:115-122.

29. Scheuermann KK, Eberhardt DS. Avaliação de fungicidas para o controle da brusone de panícula na cultura do arroz irrigado. Rev Ciências Agroveterinárias. 2011;10(1):23-28. 
30. Bradshaw C, Tjensvoll I, Sköld M, Allan IJ, Molvaer J, Magnusson J, Naes K, Nilsson HC. Bottom trawling resuspends sediment and releases bioavailable contaminants in a polluted fjord. Environm Pollution. 2012;170:232-241, doi:10.1016/j.envpol.2012.06.019.

31. Britto FB, Vasco NA, Pereira APS, Mello AVM, Nogueira LC. Herbicidas no alto Rio Poxim, Sergipe e os riscos de contaminação dos recursos hídricos. Rev Ciência Agronôm. 2012;43(2):390-398, doi: 10.1590/S1806-66902012000200024.

32. Silva DML, Camargo PB, Martinelli LA, Lanças FM, Pinto JSS, Avelar WEP. Organochlorine pesticides in Piracicaba river basin (São Paulo/Brazil): a survey of sediment, bivalve and fish. Química Nova. 2008;31(2):214-219, doi:10.1590/S0100-40422008000200005.

33. Li H, Sun B, Lydy MJ, You J. Sediment-associated pesticides in an urban stream in Guangzhou, China: implication of a shift in pesticide use patterns. Environm Toxicol Chemistry. 2013;32(5):1040-1047, doi:10.1002/etc.2147.

34. Miglioranza KSB, Gonzalez M, Ondarza PM, Shimabukuro VM, Isla FI, Fillmann G. Assessment of Argentinean Patagonia pollution: PBDEs, OCPs and PCBs in different matrices from the Río Negro basin. Science Total Environment. 2013;452-453:275-285, doi:10.1016/j.

35. Chi FH, Amy GL. Transport of anthracene and benz(a)anthracene through iron quartz and three aquifer materials in laboratory columns. Chemosphere. 2004;55(4):515-524, doi:10.1016/j.

36. Filizola HF, Ferracini VL, Aguiar Sans LM, Gomes MAF, Ferreira CJA. Monitoramento e avaliação do risco de contaminação por pesticidas em água superficial e subterrânea na região de Guaíra. Pesquisa Agropecuária Brasil. 2002;37(5):659-667.

37. Nakagome FK, Noldin JÁ, Resgalla JRC. Toxicidade aguda e análise de risco de herbicidas e inseticidas utilizados na lavoura do arroz irrigado sobre o cladócera Daphnia magna. Pesticidas: Rev Ecotoxicol Meio Ambiente. 2006;16:93-100.

38. Prado GL. Avaliação da Susceptibilidade à Contaminação de Corpos Hídricos, em Áreas de Cultivo e do Entorno (Reservas Indígenas), pelo uso de Agrotóxicos, Dissertação. Programa de Pós-Graduação em Ciências do Ambiente da Universidade Federal do Tocantins, 2013.

39. Moon JM, Chun BJ. Acute endosulfan poisoning: a retrospective study. Hum Exp Toxicol. 2009;28(5):309-316. 